\title{
PEMANFAATAN LIMBAH KULIT IKAN NILA DARI INDUSTRI FILET UNTUK KULIT JAKET
}

\author{
(REUSE OF SKIN WASTE OF NILE TILAPIA FROM FILLET \\ INDUSTRY FOR LEATHER GARMENT)
}

\author{
Prayitno, Emiliana.K., Nur Wachid S. ${ }^{1)}$ \\ Email: prayitno_bbkkp@yahoo.com \\ Diterima: 2 Maret 2012 \\ Disetujui: 18 Juni 2012
}

\begin{abstract}
The research to reuse skin waste of the Nile tilapia sp resulted from the Fish's fillet industries was done to produce leather for garment by washable tanning process. Three variable concentrations of reactive dyes, hydrophobic fat liquoring agent and anionic water repellent were used in this research by 10,15 , and $20 \%$ for reactive dyes and $10,12.5$, and $15 \%$ for both hydrophobic fat liquoring agent and water repellent resulted twenty-seventh of treatment. The research result saw that there is no fade and no change in color after washing and have a good of persperation test for all the treatment, light fastness test resulted 5 of Grey Scale whereas sofness test resulted in range of scale 4 to 6 . Tearing and sawing tests saw that for all treatment were fulfill the SNI 06-4593-1998, Garment leather from sheep and goat. Those were in range of 19.81 $\mathrm{kg} / \mathrm{cm}$ to $47.70 \mathrm{~kg} / \mathrm{cm}$ and $59.58 \mathrm{~kg} / \mathrm{cm}$ to $98.57 \mathrm{~kg} / \mathrm{cm}$ for tearing and sewing properties respectively. Whereas tensile properties saw that from the 27 treatment, 15 treatment were fulfill SNI requirement with the highest value was $171,40 \mathrm{~kg} / \mathrm{cm}^{2}$, for elongation properties for all treatment saw the result was runs between $69,30 \%$ and $110,00 \%$. Optimal conditions resulted by concentration of $10 \%$ reactive dyes, $10 \%$ hydrophobic fat liquoring and $10 \%$ anionic waterrepellent.
\end{abstract}

Foot note: Reactive dye, skin of the Nile tilapia, hydrophobic

\begin{abstract}
ABSTRAK
Telah dilakukan penelitian untuk memanfaatkan limbah kulit ikan Nila dari hasil samping industrifillet dijadikan kulit samak yang dapat digunakan untuk jaket dengan proses penyamakan yang dapat dicuci. Konsentrasi zat warna reaktif, bahan peminyakan hidrophobik dan anionik water- repellen yang digunakan dalam penelitian ini di variasi masing-masing dalam 3 konsentrasi, yaitu 10, 15 dan 20\% untuk zat warna reaktiv dan 10, 12,5 dan 15\% untuk bahan peminyakan dan water-repellen, sehingga dalam penelitian ini dilakukan sebanyak 27 perlakuan. Hasil penelitian menunjukan tidak adanya kelunturan dan perubahan warna untuk semua perlakuan pada uji pencucian dan uji ketahan terhadap keringat dengan nilai pada skala 4/5 - 5 Gray scale, dan kulit tetap lemas setelah pengujian dengan nilai kelemasan antara 4-6. Uji kuat sobek menunjukan semua perlakuan memenuhi persyaratan SNI 06-4593-1998 Kulit Jaket dari domba dan kambing dengan nilai terendah $19,81 \mathrm{~kg} / \mathrm{cm}$ dan tertinggi $47,70 \mathrm{~kg} / \mathrm{cm}$, untuk uji kuat jahit semua memenuhi persyaratan SNI, dengan nilai terendah $59,58 \mathrm{~kg} / \mathrm{cm}$ dan tertinggi 98,57 $\mathrm{kg} / \mathrm{cm}$ sedangkan untuk kuat tarik 15 perlakuan dapat memenuhi peryaratan SNI dengan nilai tertinggi $171,40 \mathrm{~kg} / \mathrm{cm}^{2}$. Sedangkan uji kemuluran kulit menunjukan hasil uji terendah $69,30 \%$ dan tertinggi $110,00 \%$. Kondisi optimal diperoleh dengan perlakuan $10 \%$ zat warna reaktive, $10 \%$ bahan peminyakan hidrophobik dan $10 \%$ bahan water-repellen anionik.
\end{abstract}

Kata kunci: zat warna reaktif, kulit ikan nila, hidrophobik

"Balai Besar Kulit, Karet dan Plastik, Yogyakarta

PEMANFAATAN LIMBAH KULIT IKAN NILA DARI INDUSTRI......(Prayitno, dkk) 


\section{PENDAHULUAN}

Industri penyamakan kulit Indonesia saat ini banyak menghadapi tantangan selain pencemaran yang ditimbulkan (Zaenab, 2008 ) juga dalam penyediaan bahan baku kulit mentah. Data terakhir (Anonim, 2007) jumlah pabrik penyamakann kulit di Indonesia untuk skala menengah dan besar ada 67 buah sedangkan untuk skala kecil dan rumah tangga ada sekitar 240 industri rumahan, dengan kapasitas terpasang 150 juta square feet hide atau sekitar 5 juta lembar kulit sapi dan 100 juta square feet skin atau sekitar 200 juta lembar kulit kambing atau domba.

Industri pemotongan dalam negeri hanya mampu menyediakan kulit mentah $40 \%$ untuk kulit sapi dan $20 \%$ untuk kulit domba/kambing. Keterbatasan bahan baku ini ditambah dengan adanya aturan-aturan impor perkulitan mengakibatkan banyaknya pengrajin kulit yang menghentikan dan pemutusan hubungan kerja. Dengan teknologi yang sudah dikuasai oleh para pengrajin dapat diupayakan untuk diterapkan pada usaha yang sama dengan diversifikasi bahan baku dan produk.

Kulit adalah merupakan produk samping dari usaha peternakan untuk diambil dagingnya sehingga ketersediaannya sangat bergantung dari tingkat konsumsi protein. Saat ini untuk pemenuhan protein masyarakat dapat dipenuhi dengan berbagai upaya diantaranya dengan meningkatkan hasil perikanan salah satunya adalah ikan. Dengan berkembangnya pembangunan perikanan di Indonesia secara umum telah berhasil meningkatkan produksi pada berbagai bidang usaha. Produksi perikanan setiap tahun mengalami peningkatan rata-rata sebesar $5,23 \%$, sedangkan konstribusi perikanan budi daya dan penangkapan ikan air tawar terhadap produksi ikan nasional sebesar 29,1\%, produksi perikanan budi daya ini terus meningkat rata-rata setiap tahunnya sebesar $20,14 \%$ dengan jumlah 1.076 .750 ton tahun 2001 menjadi 2.163.674 ton pada tahun 2005 ( Mei Dwi Erlina dkk, 2004).

Salah satu jenis ikan air tawar yang saat ini dikembangkan adalah ikan nila (Oreochronis nilaticus) yang dalam bahasa Inggris disebut Nile tilapia. Jenis ikan ini berasal dari Afrika, banyak dibudidayakan karena mudah pemeliharaannya, laju perkembangan biak dan pertumbuhannya cepat, tahan hama dan penyakit. Selain untuk konsumsi masyarakat dalam negeri, ikan nila juga telah menjadi komoditas ekspor Indonesia. Klasifikasi ikan Nila adalah sebagai berikut:

$\begin{array}{ll}\text { - Filum } & \text { :Chordata } \\ \text { - Sub. Filum } & \text { : Vertebrae } \\ \text { - Kelas } & \text { :Actinopterygii } \\ \text { - Ordo } & \text { :Perciformes } \\ \text { - Famili } & \text { :Cichlidae } \\ \text { - Genus } & \text { : Oreochromis } \\ \text { - Spesies } & \text { :Oreochromis niloticus }\end{array}$

Ekspor ikan Nila Indonesia ke Amerika tahun 2005 sebesar 1.146.331 ton dengan nilai US \$ 5.551.407 dari total ekspor ikan nila sebesar 37.544.537 ton dengan nilai US \$ 81.896.969. Ekspor ikan Nila asal Indonesia umumnya dalam bentuk fillet ( Sri Untari dkk, 2009). Hasil samping pengolahan fillet ikan nila salah satunya adalah kulit ikan yang apabila tidak ditangani dengan baik akan menjadi sumber cemaran.

Beberapa penelitian penyamakan kulit ikan telah dilakukan oleh Sri Untari dkk, 2009), melakukan penelitian penyamakan kulit ikan untuk produk kerajinan, asesoris dan sepatu. Alfindo dan Tomi, (2009) melakukan penelitian Penyamakan kulit ikan tuna (thunus,sp) menggunakan kulit kayu akasia (Acacia mangium.W) terhadap mutu fisik kulit produk kulit samak juga digunakan untuk kerajinan. Namun untuk produk garmen dikehendaki persyaratan khusus diantaranya harus lemas yang dipengaruhi bahan fatliquor yang digunakan (Palop, 2005) kuat dan dapat dicuci dengan tidak mengalami perubahan baik kenampakan maupun sifat fisikanya. Dengan teknologi penyamakan khusus, kulit ikan nila dapat menghasilkan kulit jadi yang dapat dimanfaatkan menjadi produk garmen sehingga nantinya diharapkan dapat menumbuhkan lapangan kerja bagi pengrajinpengrajin industri kulit yang terpaksa menghentikan usahanya karena keterbasan bahan baku.

Hingga saat ini permintaan akan pakaian dari kulit (garmen) tidak pernah berkurang (Sammarco, 2006). Fungsi utama pakaian 
kulit ini adalah untuk melindungi dan menghangatkan tubuh, karena selalu berhubungan dengan tubuh maka untuk menjaga pakaian kulit seperti pada fungsinya, pakaian kulit harus selalu tetap bersih. Untuk menjaga kulit tetap bersih dikehendaki adanya sifat kulit yang dapat dicuci untuk menghilangkan bentuk-bentuk kotoran pada pakaian kulit seperti keringat, debu dan kotoran-kotoran lainnya. Menurut Kiesow et al, (2006), kulit yang dapat dicuci harus memenuhi kriteria-kriteria sebagai berikut, setelah pencucian kulit harus tidak berubah sifat fisikanya seperti kuat tarik, kuat sobek, tetap lunak, tidak mengkerut, tidak terjadi pemudaran warna dan tidak luntur. Schubert et all, (2008) telah mematenkan hasil penelitian menyamak kulit yang dapat dicuci dengan menggunakan repellency dari fluorinated ester.

Untuk kriteria kulit yang dapat dicuci tidak berubah sifat fisika, tetap lunak dan tidak mengkerut dipengaruhi oleh keseluruhan proses penyamakan, jenis bahan-bahan kimia yang digunakan termasuk bahan untuk peminyakan (Boehme, 2005; Burgess, 2007), sedangkan kriteria tidak terjadi pemudaran warna dan tidak luntur ditentukan oleh zat warna serta bahan pengikat warna yang digunakan (Tsutsui et all, 1996). Pemudaran warna serta kelunturan adalah dikarenakan fiksasi yang tidak cukup kuat. Untuk pewarnaan kulit pada umumnya digunakan zat warna anionik, dimana kerjanya adalah terbentuknya ikatan ion dengan kolagen dan dengan krom yang terikat dengan kolagen. Ikatan ionik ini lemah dan dapat dipatahkan dengan adanya keringat, adanya air selama pencucian. Ini menyebabkan warna dari kulit menjadi pudar. Jenis zat warna lain adalah zat warna reaktive.

Untuk kulit yang dapat dicuci zat warna yang digunakan adalah zat warna reaktif, zat warna reaktif yang mempunyai dua gugus yaitu gugus chromophore yang akan memberikan warna dan gugus reaktif yang akan mengikat pada serabut kolagen secara irreversibel pada kondisi alkali akan membentuk ikatan kimia dengan group hidroksil jaringan kulit.

Untuk pewarnaan kulit, zat warna ini akan membentuk ikatan kovalent dengan kolagen menyebabkan zat warna tersebut terimobilisasi dalam jaringan kulit, sehingga sangat tahan terhadap muatan elektrostatik didalam permukaan bahan (Kiesow et al, 2006). Dengan zat warna reaktive warna kulit yang dihasilkan akan tahan terhadap pencucian danjuga keringat.

\section{MATERI DAN METODA PENELITIAN Bahan Penelitian}

Bahan-bahan yang digunakan dalam penelitian ini meliputi: kulit ikan Nila asal dari Aqua Farm Semarang. Bahan-bahan untuk proses basah terdiri atas: tepol, $\mathrm{Na}$ Bicarbonat, kapur, $\mathrm{Na}_{2} \mathrm{~S},\left(\mathrm{NH}_{4}\right)_{2} \mathrm{SO}_{4}, \mathrm{NH}_{4} \mathrm{Cl}$, Bating 5B, Degreasing ND, garam, katalik GS, asam formiat, asam sulfat.

Bahan untuk penyamakan terdiri atas: garam, asam formiat, kromosal $\mathrm{B}$, natrium asetat, natrium bikarbonat, natrium formiat, Relugan RE, Basyntan AN dan Pelan HGW. Bahan untuk pewarnaan Lugafast black AN. Bahan untuk peminyakan terdiri atas Imergan A, Desodrin OF, Paramit MI-N, Lipoderm Liquor WF. Bahan fiksasi: Kromitan B.

\section{Peralatan Penelitian}

Alat penelitian terdiri atas: drum penyamakan skala laboratorium, $\mathrm{pH}$ meter, gelas ukur, gelas piala, thermometer, ember plastik.

\section{Cara kerja penelitian \\ Desain Penelitian}

Penelitian dilakukan dengan menggunakan 3 variable konsentrasi zat warna reaktif dan kombinasi bahan peminyakan dan water-repellent masingmasing dengan 3 variabel konsentrasi. Sehingga dalam penelitian dilakukan sebanyak 27 perlakuan, kode perlakuan adalah sbb:

$$
\begin{aligned}
& \text { Lugavas blackAN I : } \\
& \mathrm{I}=10 \% ; \mathrm{II}=15 \% ; \text { III. }=20 \% \\
& \text { Imergan } \mathrm{A} \quad: \\
& \mathrm{A}=10 \% ; \mathrm{B}=12,5 \% ; \mathrm{C}=15 \% \\
& \begin{array}{l}
\text { Desodrin OF } \\
\mathrm{a}=10 \% ; \mathrm{b}=12,5 \% ; \quad \mathrm{c}=15 \%
\end{array}
\end{aligned}
$$


Dari 3 variabel diatas akan diperoleh 27 perlakuan, sebagai berikut:

\begin{tabular}{|c|c|c|c|c|c|c|c|c|c|}
\hline Kode & I & II & III & IV & V & VI & VII & VIII & IX \\
\hline Perlakuan & IAa & IAb & IAc & IBa & IBb & IBc & ICa & ICb & ICc \\
\hline Kode & X & XI & XII & XIII & XIV & XV & XVI & XVII & XVIII \\
\hline Perlakuan & IIAa & IIAb & IIAc & IIBa & IIBb & IIBc & IICa & IICb & IICc \\
\hline Kode & XIX & XX & XXI & XXII & XXIII & XXIV & XXV & XXVI & XXVII \\
\hline Perlakuan & IIIAa & IIIAb & IIIAc & IIIBa & IIIBb & IIIBc & IIICa & IIICb & IIICc \\
\hline
\end{tabular}

\section{Pelaksanaan Penelitian}

\section{Proses Basah (Beam House Operation)}

Kulit ikan Nila garaman setelah dilakukan penimbangan. Dilanjutkan perendaman dengan menggunakan larutan Natrium bicarbonat dan tepol selama satu jam, kemudian dilakukan penghilangan daging dengan menggunakan pisau seset. Setelah penimbangan dilanjutkan dengan proses pengkapuran dan penghilangan sisik dengan merendam dalam larutan kapur satu malam dan penggerokan sisik serta penghilangan sisa-sisa daging yang masih ada. Setelah ditimbang dilakukan proses penghilangan kapur, pengkikisan protein dan lemak dengan merendam dalam larutan dalam air, $\mathrm{NH}_{4} \mathrm{Cl}$, (NH4) $)_{2} \mathrm{SO} 4$, obat bating 5B dan bahan degreasing ND. Dilanjutkan proses pengasaman dengan menggunakan air, garam, kalatik GS, asam formiat, asam sulfat, degreasing ND dengan pengadukan sekitar 34 jam. Hasil akhir pada proses ini dihasilkan kulit pickle (Sakkar, 1995; Muchtar Lutfie, dkk, 1994).

\section{Proses Penyamakan (Tanning Process)}

Kulit pickle dilakukan penimbangan untuk menentukan berat bahan-bahan kimia yang digunakan, kemudian direndam sambil dilakukan pengadukan dalam larutan yang terdiri dari air, garam, asam formiat, kromosal $\mathrm{B}$, natrium asetat, natrium bikarbonat, selama 10 jam, dilanjutkan dengan proses retanning menggunakan larutan air, natrium formiat, natrium bikarbonat, Relugan RE, Basyntan AN dan Pelan $H G W$ diamkan satu malam. Setelah kulit dicuci dilakukan netralisasi dengan menggunakan larutan natrium format dan natrium bikarbonat dalam air suhu, $40^{\circ} \mathrm{C}$ kemudian dilakukan pengecatan dengan menggunakan zat warna reaktif Lugafast black AN pH larutan dibuat 9-10 menggunakan natrium karbonat. Setelah dicuci kemudian diatur $\mathrm{pH}$ pada 5,9 dan dilanjutkan dengan proses peminyakan menggunakan fatliquor Imergan A dan waterrepellen desodrin $O F$ dikombinasikan dengan anionik fatliquor lipoderm liquor $L A$ dan Lipoderm liquor LA dan paramit MI-N dan $\mathrm{pH}$ larutan dibuat 3,3 dengan asam formiat. Kemudian dilakukan fiksasi dengan khromitan $B$ baru dicuci. Kemudian dilakukan pengeringan dan pelemasan baru dilakukan pementangan (Flaherty, 1978; Sharphouse, 1989).

\section{Pengujian}

Pengujian sebelum dan setelah dilakukan pencucian dilakukan di Laboratorium Pengujian dan Sertifikasi terakreditasi Balai Besar Kulit,Karet dan Plastik yang telah terakreditasi dengan macam uji: kelemasan, kuat sobek, kekuatan jahit, kuat tarik dan kemuluran, ketahanan warna (keringat dan pencucian) dan perubahan dimensi. 


\section{HASIL DAN PEMBAHASAN}

Hasil pengujian kulit samak ikan Nila hasil penelitian pada setiap perlakuan dibandingkan sebelum pencucian (A) dan sesudah pencucian (B) seperti terlihat pada gambar berikut:

\section{Kelemasan}

Kelemasan kulit jaket/garmen sangat diperlukan untuk menentukan keenakan pakai dari produk barang kulitnya. Hasil uji kelemasan seperti terlihat pada Gambar 1. Dari grafik terlihat bahwa peningkatan konsentrasi bahan peminyakan akan meningkatkan kelemasan kulitnya namun pada konsentrasi minyak tertentu kelemasan justru menunjukan penurunan terlihat pada pada perlakuan VI yang kemudian naik tajam pada perlakukuan VII, hal tersebut dimungkinkan karena adanya jenis dari bahan baku kulit ikan yang memang sangat sulit untuk diseragamkan, karena sangat bergantung pada kondisi ikan.

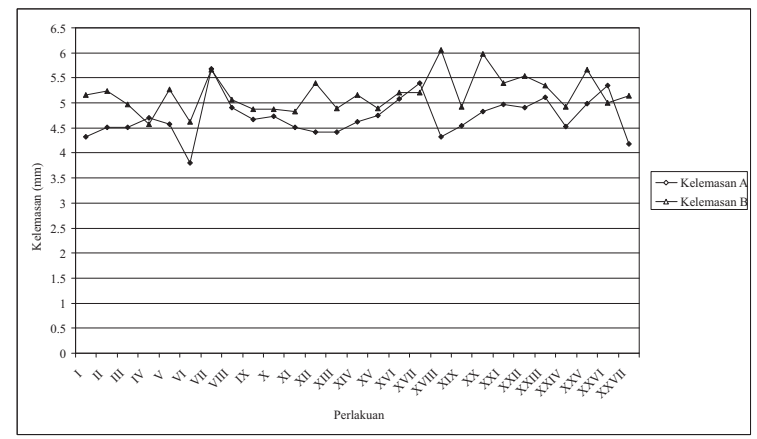

Gambar 1: Grafik uji kelemasan

Pada perlakuan yang terakhir dimana minyak digunakan merupakan kadar minyak yang paling tinggi, kelemasan mengalami penurunan, hal mana dimungkinkan karena kemampuan kulit menyerap minyak sudah mengalami kejenuhan sehingga pada proses selanjutnya minyak menjadi terlepas. Namun secara umum dengan kadar minyak yang digunakan percobaan telah memberikan kelemasan yang memadai. Setelah pencucian tingkat kelemasan kulit meningkat seiring dengan meningkatnya kadar minyak yang digunakan, hal ini menunjukan bahwa ada kemampuan kulit saat dicuci menyerap air.

\section{Kuat Sobek}

Kuat sobek disyaratkan pada kulit garmen untuk keawetan produk dalam pemakaiannya. Hasil uji kuat sobek adalah seperti terlihat pada Gambar 2. Dari grafik terlihat pada perlakuan I kuat sobek kulit samak ikan nila sebelum pencucian memberikan nilai yang paling tinggi dan kemudian menurun dengan nilai minimum $20,56 \mathrm{~kg} / \mathrm{cm}$. Jika dibandingkan dengan persyaratan kulit jaket dari domba dan kambing SNI.06-4393-1998, kuat sobek dari kulit samak ikan nila hasil penelitian dari semua perlakuan memenuhi memenuhi persyaratan minimum yang disyaratkan yaitu $13 \mathrm{~kg} / \mathrm{cm}$.

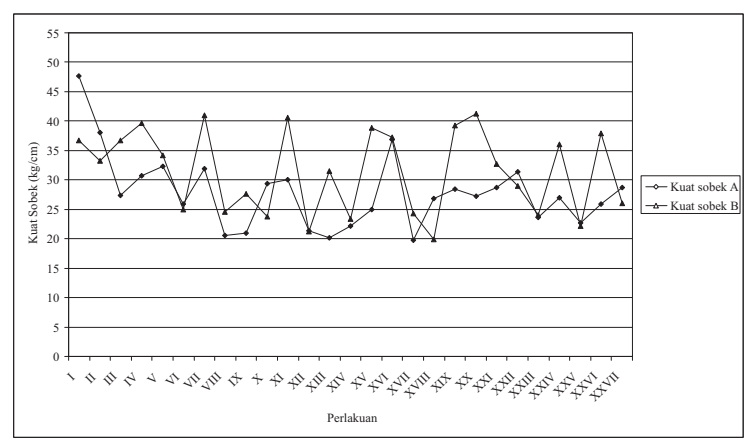

Gambar 2: Grafik uji kuat sobek

Demikian juga setelah dilakukan pencucian kuat sobek terendah dari semua perlakuan masih memenuhi persyaratan 19,92 $\mathrm{kg} / \mathrm{cm}$. Dari grafik juga terlihat adanya hasil uji yang tidak konsisten pada setiap perlakuan hal tersebut dimungkinkan karena adanya ketidak seragaman dalam bahan bakunya.

\section{Kuat jahit}

Dari Gambar 3. tampak bahwa kuat jahit maksimum sebelum pencucian terjadi pada perlakuan dengan kode $\mathrm{V}$ dengan nilai kuat jahit $102,23 \mathrm{~kg} / \mathrm{cm}$ dan kuat jahit terendah $59,58 \mathrm{~kg} / \mathrm{cm}$ pada perlakuan dengan kode XVIII, sedangkan setelah pencucian kuat jahit maksimum sebesar $101,82 \mathrm{~kg} / \mathrm{cm}$ terjadi 
pada perlakuan IV dan nilai terendah sebesar $61,33 \mathrm{Kg} / \mathrm{cm}$ pada perlakuan VII. SNI 064593-1998 untuk kulit jaket dari domba/kambing mensyaratkan kuat sobek $\min 51 \mathrm{~kg} / \mathrm{cm}$.

Dari semua perlakuan baik sebelum maupun sesudah pencucian semua memenuhi persyaratan SNI. Keadaan bahan baku kulit ikan nila sangat mempengaruhi hasil pengujian dan juga pada proses penyamakannya,

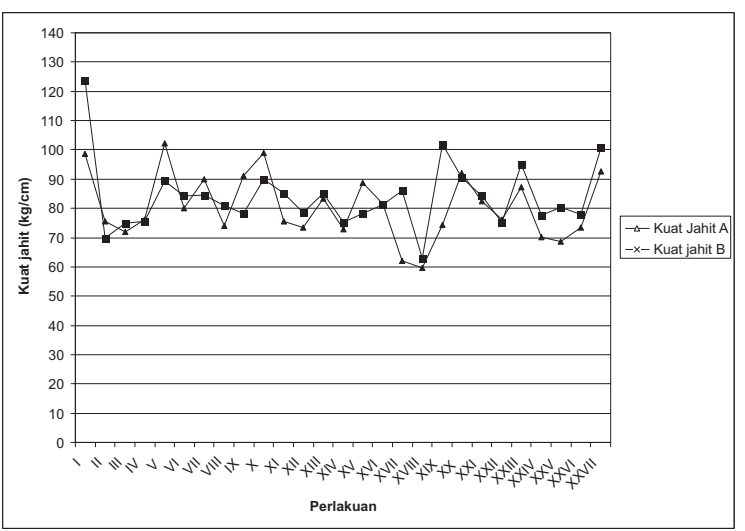

Gambar 3: Grafik uji kuat jahit

\section{Kuat tarik}

Hasil uji kuat tarik sebelum dan sesudah pencucian adalah seperti terlihat pada Gambar 4.

Dari grafik terlihat kuat tarik maksimum sebelum kulit mengalami pencucian terjadi pada perlakuan XX dengan besarnya kuat tarik $171,40 \mathrm{~kg} / \mathrm{cm}^{2}$ dan kuat tarik terendah pada perlakuan XVII sebesar $64,61 \mathrm{~kg} / \mathrm{cm}^{2}$, sedangkan persyaratan kuat tarik yang disyaratkan SNI.06-4593-1998 sebesar 120 $\mathrm{kg} / \mathrm{cm}^{2}$, dari semua perlakuan, perlakuan IV, IX, X, XI, XII, XIV, XVII, , XXI, XXII, XXV, XXVI memenuhi SNI, sedangkan perlakuan XXVII tidak memenuhi persyaratan SNI. Setelah pencucian terjadi kenaikan kuat tarik kecuali pada perlakuan III, VI, VIII, XV, XVI, XVIII, XX., kuat tarik setelah pencucian yang tidak memenuhi persyaratan SNI terjadi pada perlakuan XV. Hal tersebut kemungkinan variabelnya bahan baku serta kondisi prosesnya.

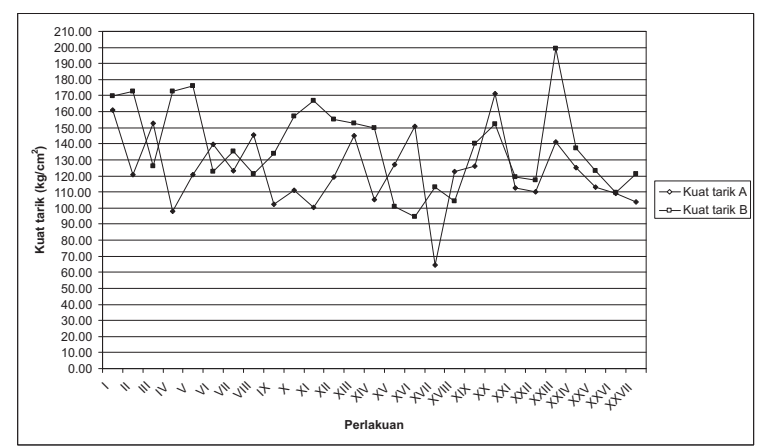

Gambar 4: Grafik uji kuat tarik

\section{Kemuluran}

Hasil uji kemuluran kulit samak ikan nila adalah seperti terlihat pada Gambar 5. Kemuluran ini menunjukan daya elastisitas kulit, untuk kulit jaket hal ini sangat diperlukan sehingga pada penggunaannya akan memberikan rasa nyaman, dalam SNI untuk jaket dari domba atau kambing dibatasi maks $60 \%$, namun pada kulit ikan nila karena kulit ini terdapat pada lembaran-lembaran kecil sehingga untuk produk jaketnya diperlukan merangkai hingga menjadi suatu lembaran maka kemuluran tidak menjadi sangat diperlukan untuk pembatasan. Kemuluran kulit ini sangat dipengaruhi oleh prosesnya terutama dalam proses peminyakan baik sebelum maupun sesudah pencucian, kemuluran kulit samak ikan Nila yang dapat dicuci hasil penelitian menunjukan adanya nilai kemuluran yang lebih tinggi dari yang disyaratkan SNI.

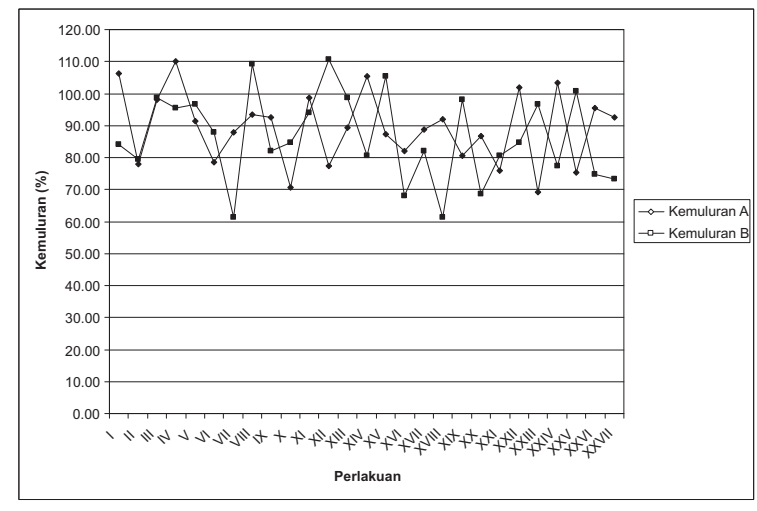

Gambar 5. Grafik uji kemuluran 


\section{Ketahanan warna terhadap keringat}

Pada pemakaiannya garmen akan selalu berhubungan dengan tubuh manusia sehingga dengan aktivitasnya manusia akan mengeluarkan keringat terutama sekali untuk daerah tropis. Sehingga bahan garmen harus mempunyai ketahanan terhadap keringat. Pengujian tingkat kelunturan digunakan jenis bahan serat katun setelah dikenakan larutan keringat buatan. Hasil uji ketahanan warna terhadap keringat seperti terlihat pada Tabel 1.
Hasil uji menunjukan sesudah pencucian dengan cairan keringat buatan tidak mengalami kelunturan, sedangkan untuk bahan serat jenis katun dan poliamida sedikit terjadi kelunturan pada perlakuan $\mathrm{V}$, untuk perlakuan IV sedikit kelunturan terjadi setelah perlakuan, namun masih memenuhi peryaratan SNI. 06-4593-1998 dengan tingkat kelunturan 4/5 skala grey scale. Dengan demikian zat warna reaktif sangat sesuai untuk kulit bahan garmen.

Tabel 1: Hasil uji ketahanan keringat

\begin{tabular}{|l|c|c|l|c|c|l|c|c|}
\hline \multirow{2}{*}{ Kode } & \multicolumn{2}{|c|}{ Grey Scale } & Kode & \multicolumn{2}{|c|}{ Grey Scale } & \multicolumn{2}{c|}{ Kode } & \multicolumn{2}{|c}{ Grey Scale } \\
\hline & A & B & & A & B & & A & B \\
\hline I & 5 & 5 & X & 5 & 5 & XIX & 5 & 5 \\
\hline II & 5 & 5 & XI & 5 & 5 & XX & 5 & 5 \\
\hline III & 5 & 5 & XII & 5 & 5 & XXI & 5 & 5 \\
\hline IV & 5 & $4 / 5$ & XIII & 5 & 5 & XXII & 5 & 5 \\
\hline V & $4 / 5$ & $4 / 5$ & XIV & 5 & 5 & XXIII & 5 & 5 \\
\hline VI & 5 & 5 & XV & 5 & 5 & XXIV & 5 & 5 \\
\hline VII & 5 & 5 & XVI & 5 & 5 & XXV & 5 & 5 \\
\hline VIII & 5 & 5 & XVII & 5 & 5 & XXVI & 5 & 5 \\
\hline IX & 5 & 5 & XVIII & 5 & 5 & XXVII & 5 & 5 \\
\hline
\end{tabular}

\section{Ketahanan warna pada pencucian}

Seperti pada uji ketahanan warna terhadap keringat, uji warna pada pencucian, pengujian juga dilakukan dengan menggunakan jenis kain katun. Hasil penelitian seperti terlihat pada Tabel 2, hasil uji menunjukan adanya sedikit kelunturan sampai $4 / 5$ grey scale dari semula 5 grey scale sebelum pencucian.

Sedikit kelunturan ini terjadi pada perlakuan III, IV, IX, XIX, XXIV, XXV. Sedikit kelunturan tersebut kemungkinan disebabkan karena fixing yang kurang atau adanya minyak yang menghalangi saat fixing terakhir. Namun kelunturan tersebut masih memenuhi SNI.

\section{Perubahan dimensi}

Hasil uji perubahan dimensi terlihat pada Tabel 3. Setelah pencucian terjadi perubahan dimensi besarnya maksimum 9,08 $\%$ pada perlakuan XXII sedangkan terkecil $3,28 \%$ pada perlakuan VIII. Untuk perubahan bentuk dibawah $5 \%$ terjadi pada perlakuan I, II,III,VII, XV, XXVII.

Perubahan dimensi ini dipengaruhi oleh kepadatan kulit, sehingga kemungkinan belum sempurnanya pada proses retaning sehingga masih dijumpai perubahan dimensi diatas $5 \%$. 
Tabel 2 : Hasil uji ketahanan warna

\begin{tabular}{|l|c|l|c|l|c|l|c|}
\hline kode & $\begin{array}{c}\text { Gray } \\
\text { scale }\end{array}$ & kode & $\begin{array}{c}\text { Gray } \\
\text { scale }\end{array}$ & Kode & $\begin{array}{c}\text { Gray } \\
\text { scale }\end{array}$ & Kode & $\begin{array}{c}\text { Gray } \\
\text { scale }\end{array}$ \\
\hline I & 5 & VIII & 5 & XV & 5 & XXII & 5 \\
\hline II & 5 & IX & $4 / 5$ & XVI & 5 & XXIII & 5 \\
\hline III & $4 / 5$ & X & 5 & XVII & 5 & XXIV & $4 / 5$ \\
\hline IV & $4 / 5$ & XI & 5 & XVIII & 5 & XXV & $4 / 5$ \\
\hline V & 5 & XII & 5 & XIX & $4 / 5$ & XXVI & 5 \\
\hline VI & 5 & XIII & 5 & XX & 5 & XXVII & 5 \\
\hline VII & 5 & XIV & 5 & XXI & 5 & & \\
\hline
\end{tabular}

Tabel. 3 : Hasil uji perubahan dimensi

\begin{tabular}{|l|c|c|c|l|c|c|c|}
\hline Kode & \multicolumn{1}{|c|}{ Kode } & $\Delta(\%)$ & Kode & $\Delta(\%)$ & Kode & $\Delta(\%)$ \\
\hline I & 4,31 & IX & 6,53 & XVII & 8,89 & XXV & 8,32 \\
\hline II & 4,97 & X & 5,76 & XVIII & 5,10 & XXVI & 5,36 \\
\hline III & 4,44 & XI & 7,94 & XIX & 5,71 & XXVII & 4,08 \\
\hline IV & 5,73 & XII & 7,9 & XX & 5,93 & & \\
\hline V & 5,73 & XIII & 6 & XXI & 5,35 & & \\
\hline VI & 8,71 & XIV & 7,9 & XXII & 9,08 & & \\
\hline VII & 8,27 & XV & 4,96 & XXIII & 8,51 & & \\
\hline VIII & 3,28 & XVI & 6,95 & XXIV & 6,35 & & \\
\hline
\end{tabular}

\section{KESIMPULAN}

Dari hasil penelitian dapat disimpulkan :

1. Kulit ikan Nila dari limbah industri fillet dapat dimanfaatkan untuk bahan baku pembuatan garmen dimana sifat fisis dan mekanisnya menyerupai kulit garmen dari kulit konvensional sesuai persyaraan SNI.06-4593-1998 Kulit jaket dari Domba/Kambing.

2. Dengan konsentrasi zat warna jenis reaktif sebesar $10 \%$, fat liquoring $10 \%$ dan water repellen $10 \%$ memberikan sifat sifat físika dan kimia yang paling optimum dengan hasil uji sebelum dan sesudah pengujian berturut-turut :kuat tarik 71,40 dan $123,81 \mathrm{~kg} / \mathrm{cm}^{2}$, kemuluran 98,57 dan $123,81 \%$, kuat sobek 47,70 dan 36,74 $\mathrm{kg} / \mathrm{cm}$, kuat jahit 98,57 dan $123,81 \mathrm{~kg} / \mathrm{cm}$ kelemasan 4,32 dan 5,16 dan menghasilkan kulit yang tidak luntur, baik untuk ketahanan keringat maupun ketahanan terhadap pencucian dan perubahan dimensi. 


\section{DAFTAR PUSTAKA}

Alfindo dan Tomi, 2009. Penyamakan Kulit Ikan Tuna (Thunus, sp) Menggunakan Kulit Kayu Akasia ( Acacia Mangium Welold) Terhadap Mutu Fisik Kulit; http://repository.ipb.ac.id/handle/12345 6789/14165.

Anonim, 2007. Profil Spesifikasi Kulit Tersamak Indonesia; USAID, SENADA, APKI, APRISINDO, Jakarta

Boehme, M.P., 2005. Fatliquor for Wasable Leather.World Leather. Vol.19 no.3 p.21-27.

Burgess, D., 2007. Fatliquors and Fatliquoring: a brief insight part 1; Word leather Vol.20, no. 6 p.36-38.

Flaherty, F., Roddy, W.T. and Lollar, R.M., 1978. The Chemistry and Technology of Leather.Vol.1-Preparation for Tannage. Robert E Krieger Publishing Company, Huntington, New York.

Kiesow, H., Somogyi, L. and Wolf, G., 2006. A New Generation of Washable Leather: Reaktive Dyes for Wet Blue and Wet White; World leather Vol 19,No.6 p.3741.

Mei D.E, Yayan H dan Saptanto S., 2004. Adopsi Teknologi Pembenihan Ikan Nila (Tilapia sp) di Jawa barat; Journal Penelitian Perikanan Indonesia Ed. Sosial Ekonomi, Vol. 10, No. 7,91-100.

Muchtar Lutfie, Meiyanti, Esti Rahayu dan Riana Rachmi, 1994. Teknologi Penyamakan Ikan Kakap. Bulletin Sains dan Teknologi Kulit Nomor 3 Th. III Juni 1994 Hal. 46-54.

Palop, R., 2005, The influence of The fatliquor on The physico-chemical Properties of Leather; Leather International July 2005, Cromogenia-Units SA, Barcelona (Spain), p. 30-32.
Sammarco, U., 2006. Automobile leather Manufacture ;World Leather October 2006, vol.19, no.6, p.31-35.

Sarkar, K.T., 1995. Theory and Practice of Leather Manufacture, Published by The Author 4, Second Avenue, Madras .

Sharphouse, J.H., 1989. Leather Technician's Hand Book; Leather Producer Assosiation, London

SNI 06-4593-1998, Anonim, Kulit Jaket dari Domba/Kambing. Badan Standardisasi Nasional, Indonesia.

Thorstensen.T.C., 1985; Practical Leather Technology; Robert.E.Krieger Publising Company, Florida. (tidak diacu).

Schubert, K.V., Liu, H.H. dan Scheen, H.J., 2008. Washable Leather with Repellency; Patent no. US 20080196168, E.L. Du Pont de Nemours and Company. Published 2008-08-21.

Sri Untari, Emiliana, Suliestiyah Wrd, Sri Sutyasmi dan Jaka Susilo, 2009. Panduan Teknis Teknologi Penyamakan Kulit Ikan. Balai Besar Kulit, Karet dan Plastik, Yogyakarta.

Tsutsui, M., Yukita, T., Takeda, M., Sugita, M. dan Arima, S., 1996. The IIIrd Asian International Conference of Leather Science and Technology; Himeji city, Japan, September -11,1996, p. 413-417.

Zaenab, 2008. Industri Penyamakan Kulit dan Dampaknya Terhadap Lingkungan, http://www.keslingmks.wordpress.com /2008/08/18/penyamakankulit. 